\begin{tabular}{r|l|l|l}
$\begin{array}{c}\text { Case Reports in } \\
\text { Gastroenterology }\end{array}$ & $\begin{array}{l}\text { Case Rep Gastroenterol 2011;5:95-99 } \\
\text { DOl: 10.1159/000324399 }\end{array}$ & $\begin{array}{l}\text { Published online: } \\
\text { February 5, 2011 }\end{array}$ & $\begin{array}{l}\text { O 2011 S. Karger AG, Basel } \\
\text { ISSN 1662-0631 } \\
\text { www.karger.com/crg }\end{array}$ \\
\hline
\end{tabular}

\title{
Response to Modified TEGAFIRI in a Patient with Synchronous Multiple Liver Metastases of Colon Cancer
}

\author{
Takanori Goi Youhei Kimura Katsuji Sawai \\ Mitsuhiro Morikawa Kanji Katayama Akio Yamaguchi \\ First Department of Surgery, University of Fukui, Fukui, Japan
}

\section{Key Words}

Colon cancer · Metastasis · Leucovorin · Tegafur-uracil · Irinotecan

\begin{abstract}
We report the case of a patient with colon cancer accompanied by multiple unresectable liver metastases who showed complete response (CR) to modified TEGAFIRI (mTEGAFIRI) (tegafur-uracil/leucovorin+irinotecan) chemotherapy. The patient was a 58-year-old Japanese male with cancer of the descending colon accompanied by multiple unresectable liver metastases. Following resection of the sigmoid colon cancer, mTEGAFIRI chemotherapy was administered. Abdominal computed tomography performed upon completion of 12 courses of chemotherapy showed that the unresectable liver metastatic lesions had disappeared, indicating CR. The only adverse drug reactions (ADRs) experienced to date have been stomatitis (grade 1) and neutropenia (grade 1). Anticancer therapy has thus been continued, and CR has been maintained for 15 months. The present patient achieved CR in response to mTEGAFIRI chemotherapy, a regimen that has not previously been reported, while experiencing only mild ADRs and maintaining a good quality of life. mTEGAFIRI chemotherapy is convenient to administer and is thought to be a potentially useful treatment option for patients with unresectable, recurrent colon cancer.
\end{abstract}

\section{Introduction}

There have been remarkable advances in chemotherapy for unresectable, recurrent colon cancer in recent years. The main chemotherapy regimens are FOLFOX and FOLFIRI, which consist of combinations of 5-fluorouracil, irinotecan, oxaliplatin and leucovorin (LV), and efficacy rates of approximately $50-60 \%$ have been reported $[1,2]$. More recently, molecularly targeted drugs, such as bevacizumab, cetuximab and 


\begin{tabular}{r|l|l|l}
$\begin{array}{r}\text { Case Reports in } \\
\text { Gastruanteriology }\end{array}$ & $\begin{array}{l}\text { Case Rep Gastroenterol 2011;5:95-99 } \\
\text { DOI: 10.1159/000324399 }\end{array}$ & $\begin{array}{l}\text { Published online: } \\
\text { February 5, 2011 }\end{array}$ & $\begin{array}{l}\text { O 2011 S. Karger AG, Basel } \\
\text { ISSN 1662-0631 } \\
\text { www.karger.com/crg }\end{array}$ \\
\hline
\end{tabular}

panitumumab, have been developed and have been successful in further extending patient survival [3-5]. In general, when these drugs are administered on an outpatient basis, it is necessary to insert a port in order to secure a central venous route. However, this treatment method entails various disadvantages. For example, there are complications associated with creation of the port, and there are subsequent cosmetic issues and long periods of time that the patient is required to remain in hospital. There is also the inconvenience associated with wearing the drug reservoir in case of continuous drug administration, as well as adverse drug reactions (ADRs) $[6,7]$.

Recent reports for unresectable and recurrent colon cancer have documented response rates of 33-41.7\% and efficacy in the case of administration of TEGAFIRI, a combination of oral and intravenous anticancer drugs (LV at $90 \mathrm{mg} /$ day and tegafur-uracil (UFT) at $250 \mathrm{mg} / \mathrm{m}^{2} /$ day in three divided doses per day for 14 days, plus 1.5 -hour infusion of irinotecan at $240 \mathrm{mg} / \mathrm{m}^{2}$ on day 1) [8,9]. However, ADRs, including grade 3/4 neutropenia, nausea, emesis and diarrhea, manifested in $10-20 \%$ of patients. Accordingly, we took into consideration the results reported by Etienne-Grimaldi et al. [10] and Hoff et al. [11], and devised the modified TEGAFIRI (mTEGAFIRI) regimen (LV at $50 \mathrm{mg} /$ day and UFT at $300 \mathrm{mg} / \mathrm{m}^{2} /$ day, both in two divided doses per day for 14 days, plus 1.5 -hour infusion of irinotecan at $100 \mathrm{mg} / \mathrm{m}^{2}$ on day 1) with the objectives of minimizing ADRs and making administration more convenient. We then employed this new regimen to treat a Japanese male with synchronous multiple liver metastases of colon cancer. That patient achieved complete response (CR), and the details of this case are reported below.

\section{Case Report}

The patient was a 58-year-old Japanese male who presented with a chief complaint of lower abdominal pain. His personal and familial medical histories included nothing of note. A blood work-up showed no abnormalities of leukocyte, erythrocyte or platelet counts, and the biochemical test results for total bilirubin, liver enzymes, alkaline phosphatase, and serum creatinine were all within normal ranges. Analysis of tumor markers found that CEA was normal at $1.7 \mathrm{ng} / \mathrm{ml}$ (normal: $\leq 5 \mathrm{ng} / \mathrm{ml}$ ), whereas CA19-9 was abnormally elevated at $137.5 \mathrm{U} / \mathrm{ml}$ (normal: $\leq 37 \mathrm{U} / \mathrm{ml}$ ). Barium enema and colon fiberscopy confirmed the presence of a large, $4 \times 4 \mathrm{~cm}$ tumor in the descending colon. Biopsy confirmed that the tumor was an adenocarcinoma. A computed tomography (CT) scan showed multiple metastatic

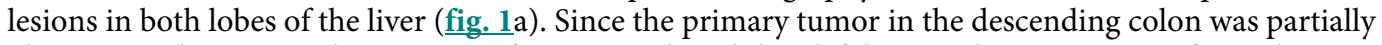
obstructing the intestinal tract, it was first resected, and then left hemi-colectomy was performed. In accordance with the TNM classification, the tumor was diagnosed as T3, N2, M1 (multiple, unresectable metastatic lesions were present in both lobes of the liver, stage IV). Postoperative recovery was uneventful. 5 weeks after surgery, levels of the tumor marker CA19-9 had become normal at $18.2 \mathrm{U} / \mathrm{ml}$. When informed consent was obtained for treatment aimed at the unresectable liver metastatic lesions, the patient desired that any ADRs be mild, that he be able to continue work as usual, that an indwelling port and hospitalization be avoided, and that the number of required visits to the hospital be minimized. In consideration of these desires, it was decided to use the mTEGAFIRI regimen.

The abdominal CT taken following completion of 6 courses of the mTEGAFIRI regimen is shown in figure $1 \mathrm{~b}$. The largest metastatic lesion in the liver had decreased in size from $3 \times 3 \mathrm{~cm}$ to $0.5 \times 0.5 \mathrm{~cm}$, and the other lesions also tended to be reduced in size. Based on the RECIST criteria, a partial response was confirmed. The abdominal CT taken following completion of 12 courses of the mTEGAFIRI regimen ( 9 months after starting chemotherapy) is shown in figure $1 \mathrm{c}$, and the results indicated CR. To date, the patient has completed 32 courses of the mTEGAFIRI regimen (CR has been maintained for 15 months), and CR continues.

ADRs were judged in accordance with the National Cancer Institute's Common Toxicity Criteria. There were no ADRs during the first 2 courses of chemotherapy, and therapy was continued. After 


\begin{tabular}{r|l|l|l} 
Case Reports in & $\begin{array}{l}\text { Case Rep Gastroenterol 2011;5:95-99 } \\
\text { DOl: 10.1159/000324399 }\end{array}$ & $\begin{array}{l}\text { Published online: } \\
\text { February 5, 2011 }\end{array}$ & $\begin{array}{l}\odot \text { ISSN 1662-0631 } \\
\text { www.karger.com/crg }\end{array}$ \\
\hline
\end{tabular}

starting the third course, grade 1 stomatitis manifested, but was alleviated by the use of an ointment. The only other ADR that manifested during the chemotherapy was grade 1 neutropenia, and there has been no occurrence of any gastrointestinal symptoms such as anorexia or nausea.

\section{Discussion}

The National Comprehensive Cancer Network Clinical Practice Guidelines in Oncology [12] and the Japanese Colorectal Cancer Treatment Guidelines [13] list 5-fluorouracil as the main drug for chemotherapy of advanced, recurrent colon cancer, along with irinotecan, oxaliplatin, bevacizumab, cetuximab and panitumumab [1-5]. However, due to an increase in the types of drugs available and the combinations in which they are used, various problems have arisen, such as the need to establish an administration route and the specific ADRs associated with these drugs [6, 7]. The most frequently used regimens are FOLFOX and FOLFIRI, and when these regimens are administered on an outpatient basis, it is generally necessary to insert a port in order to secure a central venous route. At the time of insertion, there can be complications, including pneumothorax, hemothorax and arterial puncture, and then there are cosmetic issues after insertion. In addition, it is generally necessary for the patient to visit the hospital every 2 weeks for treatment and the time needed for drug administration is long, as is the time the patient is detained in the hospital. There is also the inconvenience associated with wearing the drug reservoir. The ADRs reportedly occurring with the FOLFOX regimen, particularly those associated with oxaliplatin, include symptoms of peripheral neuropathy, such as numbness of the fingertips, and manifest in approximately $18-30 \%$ of all patients $[6,7]$. It has also been reported that sensory impairment can persist for long periods of time, and this can cause various impediments in the course of daily life and work [14].

With the goal of minimizing these issues, treatment regimens for unresectable recurrent colon cancer that consist of combinations of oral and intravenous anticancer drugs have been developed. Examples of such oral agents are LV and UFT, which are recommended in the Japanese Colorectal Cancer Treatment Guidelines [13]. UFT is a fluoropyrimidine anticancer drug. The active metabolite of this drug, FdUMP, forms complexes with thymidylate synthase (TS) and inhibits its activity, thereby inhibiting DNA synthesis and suppressing tumor growth. In addition, the active metabolite of LV, 5,10-CH2-THF, forms strong complexes with FdUMP and TS, thereby delaying the dissociation of TS and further intensifying the antitumor effect of UFT. The administered dose of LV differs depending on the protocol employed, but the response rate does not necessarily show dose dependence. In addition, the effective concentration of 5,10-CH2-THF differs as a function of the duration of contact and has been reported to be $1 \mu \mathrm{M}$ as well as $10 \mu \mathrm{M}$. Thus, there is no consensus regarding the effective concentration of 5,10-CH2-THF. The commonly used doses of LV and UFT have been, respectively, $75 \mathrm{mg} /$ day and $250-300 \mathrm{mg} / \mathrm{m}^{2} /$ day (both administered in three divided doses per day). However, Etienne-Grimaldi et al. [10] took into consideration patient convenience and investigated the AUC in the case of twice daily administration. They reported that administration in two divided doses per day resulted in AUCs for fluorouracil and uracil that were approximately two-fold those in the case of administration in three divided doses per day. In addition, Hoff et al. [11] carried out a phase II clinical study of LV (50 mg/day) and UFT ( $250-300 \mathrm{mg} / \mathrm{m}^{2} /$ day) administered in two divided doses per day and reported that both efficacy and safety were equivalent to 


\begin{tabular}{c|l|l|l}
$\begin{array}{r}\text { Case Reports in } \\
\text { Gastruenterology }\end{array}$ & $\begin{array}{l}\text { Case Rep Gastroenterol 2011;5:95-99 } \\
\text { DOI: 10.1159/000324399 }\end{array}$ & $\begin{array}{l}\text { Published online: } \\
\text { February 5, 2011 }\end{array}$ & $\begin{array}{l}\text { O 2011 S. Karger AG, Basel } \\
\text { ISSN 1662-0631 } \\
\text { www.karger.com/crg }\end{array}$ \\
\hline
\end{tabular}

administration in three divided doses per day. Saltz et al. [15] added irinotecan to the LV/UFT combination and reported that it showed greater efficacy than LV/UFT alone, while safety was also maintained. Based on those findings, we devised and were the first to test the mTEGAFIRI regimen.

In the present patient, mTEGAFIRI chemotherapy to treat unresectable, multiple liver metastatic lesions caused only mild ADRs while achieving CR. To date, CR is being maintained after one year of therapy. We therefore consider mTEGAFIRI chemotherapy to be a potentially useful treatment option for patients with unresectable, recurrent colon cancer.

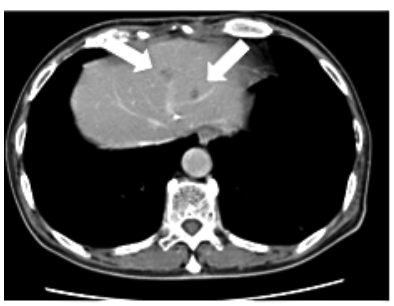

Figure1a (before treatment)

\section{Figure1b (mTEGAFIRI completion of 6courses)}
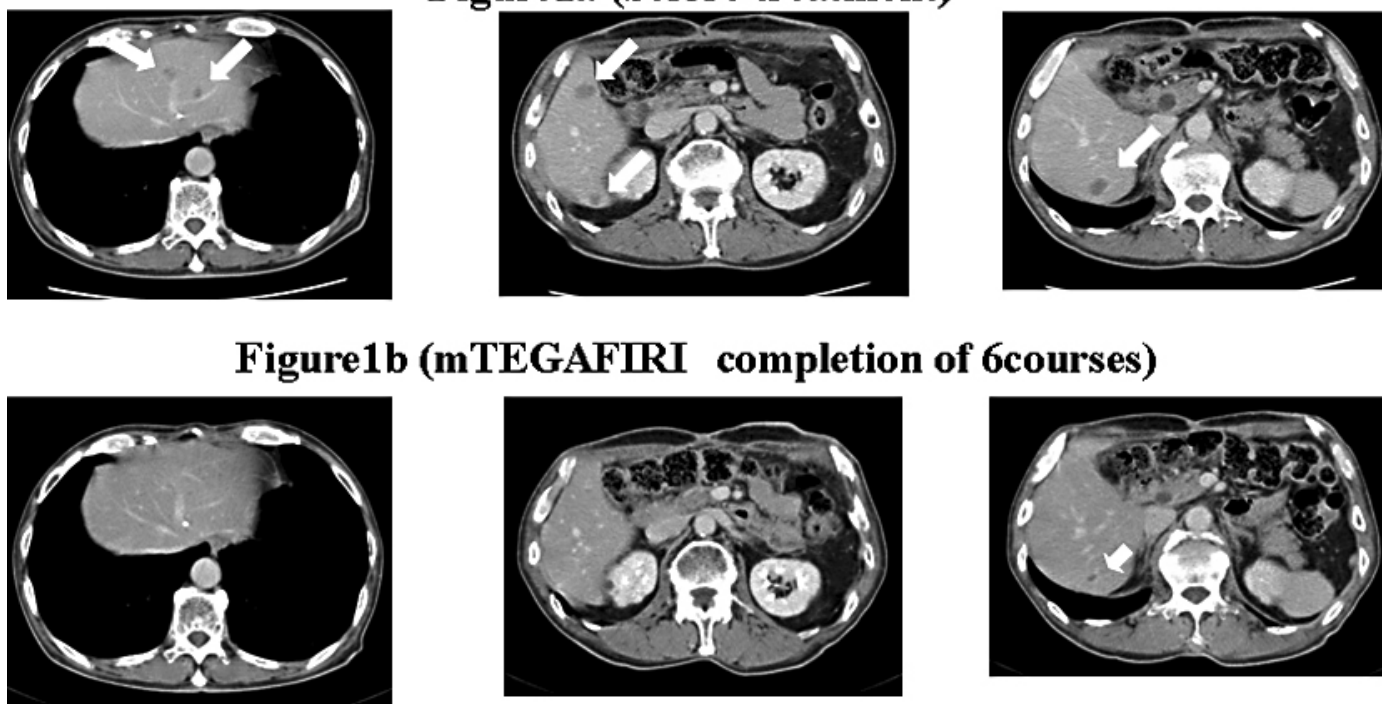

Figure1c (mTEGAFIRI completion of 12 courses)
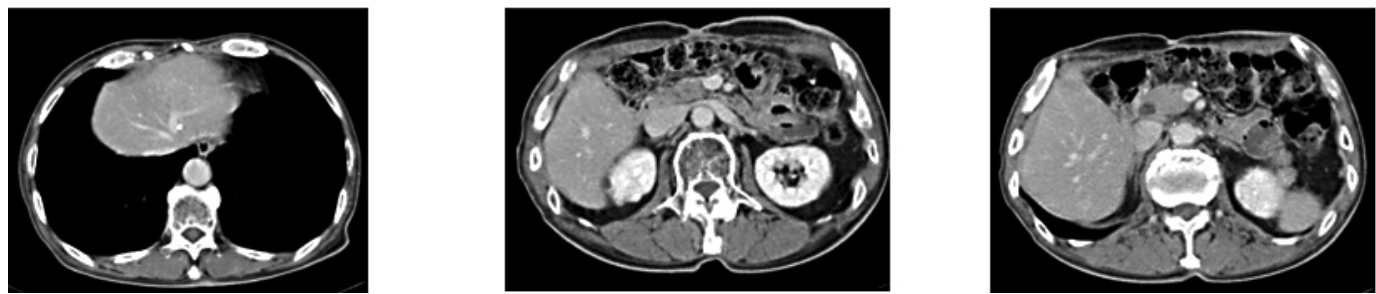

Fig. 1. a A CT scan before treatment showed multiple metastatic lesions in both lobes of the liver.

b After completion of 6 courses of mTEGAFIRI the largest metastatic lesion in the liver had decreased in size from $3 \times 3 \mathrm{~cm}$ to $0.5 \times 0.5 \mathrm{~cm}$, and the other lesions also tended to be reduced in size. c After completion of 12 courses of mTEGAFIRI the multiple metastatic lesions in both lobes of the liver had disappeared, indicating CR. 


\begin{tabular}{r|l|l|l}
$\begin{array}{r}\text { Case Reports in } \\
\text { Gastruanteriology }\end{array}$ & $\begin{array}{l}\text { Case Rep Gastroenterol 2011;5:95-99 } \\
\text { DOI: 10.1159/000324399 }\end{array}$ & $\begin{array}{l}\text { Published online: } \\
\text { February 5, 2011 }\end{array}$ & $\begin{array}{l}\text { O 2011 S. Karger AG, Basel } \\
\text { ISSN 1662-0631 } \\
\text { www.karger.com/crg }\end{array}$ \\
\hline
\end{tabular}

\section{References}

1 Goldberg RM, Sargent DJ, Morton RF, Fuchs CS, Ramanathan RK, Williamson SK, Findlay BP, Pitot HC, Alberts SR: A randomized controlled trial of fluorouracil plus leucovorin, irinotecan, and oxaliplatin combinations in patients with previously untreated metastatic colorectal cancer. J Clin Oncol 2004;22:23-30.

-2 Douillard JY, Cunningham D, Roth AD, Navarro M, James RD, Karasek P, Jandik P, Iveson T, Carmichael J, Alakl M, Gruia G, Awad L, Rougier P: Irinotecan combined with fluorouracil compared with fluorouracil alone as first-line treatment for metastatic colorectal cancer: a multicentre randomised trial. Lancet 2000;355: 1041-1047.

-3 Saltz LB, Clarke S, Díaz-Rubio E, Scheithauer W, Figer A, Wong R, Koski S, Lichinitser M, Yang TS, Rivera F, Couture F, Sirzén F, Cassidy J: Bevacizumab in combination with oxaliplatin-based chemotherapy as first-line therapy in metastatic colorectal cancer: a randomized phase III study. J Clin Oncol 2008;26:2013-2019.

-4 Van Cutsem E, Köhne CH, Hitre E, Zaluski J, Chang Chien CR, Makhson A, D’Haens G, Pintér T, Lim R, Bodoky G, Roh JK, Folprecht G, Ruff P, Stroh C, Tejpar S, Schlichting M, Nippgen J, Rougier P: Cetuximab and chemotherapy as initial treatment for metastatic colorectal cancer. N Engl J Med 2009;360:1408-1417.

5 Siena S, Cassidy J, Tabemero J, Burkes RL, Barugel ME, Humblet Y, Cunningham D, Xu F, Gansert JL, Douillard J: Randomized phase III study of panitumumab ( $\mathrm{p}$ mab) with FOLFOX4 compared to FOLFOX4 alone as first-line treatment (tx) for metastatic colorectal cancer (mCRC): PRIME trial. 2010 Gastrointestinal Cancers Symposium (abstract 283)

-6 Tournigand C, André T, Achille E, Lledo G, Flesh M, Mery-Mignard D, Quinaux E, Couteau C, Buyse M, Ganem G, Landi B, Colin P, Louvet C, de Gramont A: FOLFIRI followed by FOLFOX6 or the reverse sequence in advanced colorectal cancer: a randomized GERCOR study. J Clin Oncol 2004;22:229-237.

-7 de Gramont A, Figer A, Seymour M, Homerin M, Hmissi A, Cassidy J, Boni C, Cortes-Funes H, Cervantes A, Freyer G, Papamichael D, Le Bail N, Louvet C, Hendler D, de Braud F, Wilson C, Morvan F, Bonetti A: Leucovorin and fluorouracil with or without oxaliplatin as first-line treatment in advanced colorectal cancer. J Clin Oncol 2000;18:2938-2947.

8 Bajetta E, Di Bartolomeo M, Buzzoni R, Mariani L, Zilembo N, Ferrario E, Lo Vullo S, Aitini E, Isa L, Barone C, Jacobelli S, Recaldin E, Pinotti G, Iop A: Uracil/ftorafur/leucovorin combined with irinotecan (TEGAFIRI) or oxaliplatin (TEGAFOX) as first-line treatment for metastatic colorectal cancer patients: results of randomised phase II study. Br J Cancer 2007;96:439-444.

-9 Delord JP, Bennouna J, Artru P, Perrier H, Husseini F, Desseigne F, François E, Faroux R, Smith D, Piedbois P, Naman H, Douillard JY, Bugat R: Phase II study of UFT with leucovorin and irinotecan (TEGAFIRI): first-line therapy for metastatic colorectal cancer. Br J Cancer 2007;97:297-301.

-10 Etienne-Grimaldi MC, François E, Cardot JM, Renée N, Douillard JY, Gamelin E, Bennouna J, Château Y, Milano G: A clinical pharmacokinetic analysis of tegafur-uracil (UFT) plus leucovorin given in a new twice-daily oral administration schedule. Clin Pharmacokinet 2007;46:953-963.

11 Hoff PM, Kopetz S, Thomas MB, Langleben A, Rinaldi D, Anthony L, Wolff RA, Lassere Y, Abbruzzese JL: A phase II study of UFT with leucovorin administered as a twice daily schedule in the treatment of patients with metastatic colorectal cancer. Br J Cancer 2008;99:722-726.

12 National Comprehensive Cancer Network: NCCN Clinical Practice Guidelines in Oncology ${ }^{\mathrm{TM}}$, Colon cancer, Rectal cancer. V.I. 2010, www.nccn.org.

13 JJSCCR Guidelines 2010 for the treatment of colorectal cancer, Japanese Society for Cancer of the Colon and Rectum. Tokyo, Kanehara, 2010.

14 André T, Boni C, Navarro M, Tabernero J, Hickish T, Topham C, Bonetti A, Clingan P, Bridgewater J, Rivera F, de Gramont A: Improved overall survival with oxaliplatin, fluorouracil, and leucovorin as adjuvant treatment in stage II or III colon cancer in the MOSAIC trial. J Clin Oncol 2009;27:3109-3116.

-15 Saltz LB, Douillard JY, Pirotta N, Alakl M, Gruia G, Awad L, Elfring GL, Locker PK, Miller LL: Irinotecan plus fluorouracil/leucovorin for metastatic colorectal cancer: a new survival standard. Oncologist 2001;6:81-91. 